\title{
WHY U.S.-ENFORCED INTERNATIONAL FLIGHT SUSPENSION DUE TO DEFICIENT FOREIGN AIRPORT SECURITY SHOULD BE A No-Go
}

\section{INTRODUCTION}

According to current projections, scheduled international passenger air traffic will double by the year 2000 , growing at an average annual rate of six to seven percent in this decade. ${ }^{1}$ There are several reasons for this increase, the most prominent being advancement in technology. Technological advancement has allowed for the development of faster, larger aircraft that are able to haul greater numbers of persons for longer periods of time. ${ }^{2}$

Accompanying these impressive accomplishments, and the everincreasing number of international travelers, is a real concern about the international traveling public's safety. Because modern technology makes international travel more and more commonplace, it is also reasonable to assume that travelers expect safety standards between countries to be fairly common. That is, travelers have come to expect that the safety standards adhered to in the country of departure will mirror the standards in the destined country. Among these safety expectations are standards regarding equipment, personnel training, flight, and airport security.

This Comment analyzes certain laws, regulations and international agreements that delineate responsibilities, duties and procedures with respect to international flight suspension due to substandard foreign airport security. It exposes certain aspects of United States law [hereinafter, federal law] that effectuate undesirable economic consequences while not necessarily accomplishing their intended purpose--to safeguard the United States' international flying public. In conclusion, general recommendations are offered indicating how federal and international law may better serve international aviation and the safety of the international flying public.

The Federal Aviation Act of 1958 [hereinafter, the Aviation Act] is analyzed with respect to the factors the Secretary of the Department of Transportation [hereinafter, DOT Secretary] considers when acting on behalf of the public interest with respect to foreign airport security standards. Also, the Foreign Airport Security Act [hereinafter, The Security Act],

1. Chuck Y. Gee, Dean, Aviation and Tourism: The Traveling Public, 20 Transp. L. J. 1, 2 (1991).

2. For example, consider the Boeing $747-400$ and the McDonnell-Douglas MD-11. Although both aircraft are recent versions of their predecessors, the Boeing 747 and the McDonnell Douglas DC-10, their advanced modifications make it possible to maintain cruising altitudes and speeds for over 8,000 miles at once. This allows people to travel nearly halfway around the world non-stop and remain airborne for fifteen hours at a time or more. Also, the size of such aircraft make it possible for more people to travel at once, which increases profit potential. 
signed into law as part of the International Security and Development Cooperation Act of 1985 and later incorporated into the Aviation Act, is analyzed at length. The Security Act equips the United States Government with legal engines for assessing foreign airport security and taking subsequent action with respect thereto.

References are also made to other legal instruments affecting the enforcement of foreign airport security standards and subsequent governmental action. The Convention on International Civil Aviation [hereinafter, The Chicago Convention] and its Annex 17, dealing with international airport security standards and procedures, provide international authority allowing the United States to act outside its territorial jurisdiction. Also, several Bilateral Air Transport Agreements, made separately between the U.S. and other countries for the purpose of conducting air transportation with each of those countries, will be discussed. These contracts give the U.S. Government latitude in enforcing decisions in the global arena, such as flight suspension.

To illustrate the practical impact of the aforementioned laws and procedures, a real situation is discussed in which the U.S. Government determined a foreign international airport to be security-deficient. As a result of the alleged deficiency, the DOT Secretary suspended domestic air carrier flights and foreign air carrier flights that operated directly between that airport and the United States. By analyzing this fact pattern with regard to the abovereferenced legal processes, this Comment illuminates deficiencies in the law, recommends how and why the law should be modified, and contemplates other laws that the legal and political community may enact to produce better results.

\section{American Trans Air and the Murtala MuHammed INTERNATIONAL AIRPORT}

On August 11, 1993, the DOT Secretary effectively denied all air carriers the ability to operate between the United States and Lagos, Nigeria. $^{3}$ To accomplish this, the DOT Secretary suspended all flights operating directly between any airport within the territorial jurisdiction of the United States and the Murtala Muhammed International Airport located in Lagos, Nigeria. ${ }^{4}$ This suspension, which became effective immediately and

3. DOT Suspends Travel to Lagos, Nigeria Airport, Says it Lacks EffectiveSecurity Measures, United States Department of Transportation, 1993 WL 311897, August 11, 1993 [hereinafter, United States Department of Transportation News Release].

4. Id. 
continues indefinitely, ${ }^{5}$ applied to both U.S. air carriers ${ }^{6}$ and foreign air carriers operating flights between the United States and Lagos. ${ }^{7}$ The Lagos airport's failure to maintain and administer effective security measures, coupled with the DOT Secretary's finding that the airport created a "condition" that threatened the safety and security of passengers, aircraft and crews traveling to or from the Lagos airport, formed the basis authorizing the suspension. ${ }^{8}$

The DOT Secretary's flight suspension directly affected the operations of American Trans Air (ATA), a U.S. passenger air carrier based in Indianapolis, Indiana. 9 ATA offers scheduled service between various points in the United States and cities in foreign countries, including Lagos, Nigeria. ${ }^{10}$ The Secretary's suspension applied to ATA because it was a carrier offering service directly between the United States and Lagos. The flight suspension forced ATA to refund tickets it had issued for passage to and from Lagos. ${ }^{11}$

The suspension action by the DOT Secretary, however, did not necessarily keep passengers from traveling to the Lagos airport. Upon finding that direct flights to Lagos, Nigeria originating from the United States were suspended, passengers originally routed on such flights simply changed their routes. Passengers traveled to a U.S. gateway city, boarded a flight that was

5. At the time of this Comment's publication, the DOT Secretary's suspension order remained effective.

6. An aircraft's nationality is technically determined by the country in which it is registered, not necessarily by the country in which the airline operates or is incorporated. See The Convention on International Civil Aviation, Dec. 7, 1944, art. 17, 61 Stat. 1180, 1185 T.I.A.S. 1591, 15 U.N.T.S. 295 (entered into force April 14, 1947); The Federal Aviation Act of 1958, Pub. L. No. 85-726, 72 Stat. 737, tit. V, 8501; Aircraft Registration, 14 C.F.R. $\$ 47$ et. seq. (1993).

7. Id.

8. See U.S. Department of Transportation News Release, supra note 3, at 1.

9. The analysis, conclusion, or any other views expressed in this Comment are those of the author only, and are not necessarily the views of American Trans Air, or any of its executives, agents, assignees, employees, or any other person or entity in any way associated with American Trans Air.

10. See e.g. Applications for Certificates of Public Convenience and Necessity and Foreign Air Carrier permits filed Under Subpart Q During the Week Ended June 19, 1992, (DOT Notice) 57 Fed. Reg. 28,897-03 (1992). This document states that the DOT received the "Application of American Trans Air, Inc. pursuant to section 401 of the [Aviation] Act and subpart $Q$ of [title 14 of] the [code of Federal] Regulations [section 302.1701 et seq.], [which] applies for a certificate of public convenience and necessity authorizing it to provide scheduled foreign air transportation of persons, property and mail between any points or points in the United States and Lagos, Nigeria."

11. Memorandum from ATA to its employees discussing refund procedures (Aug. 12, 1993) (on file with author). 
not destined for Lagos, flew to a foreign city, and then negotiated passage from that city to Lagos. ${ }^{12}$

For example, a passenger prohibited by the DOT Secretary's suspension order from traveling directly to Lagos from the United States (via ATA, any other U.S. carrier, or foreign carriers) could, instead, board a plane in the United States destined for London, England. After arriving in London, this passenger could take a another flight to Lagos. Though hampered by additional inconvenience and a lengthier journey, a passenger could, in effect, nullify the DOT Secretary's efforts to keep the flying public away from the Lagos airport. Also, the same foreign air carrier that delivered such a passenger to Lagos indirectly, via an intermediate foreign airport, could be the same foreign carrier suspended from offering flights directly to and from the United States and Lagos. Therefore, such a foreign air carrier ultimately could receive the business of passengers prohibited from traveling on U.S. air carriers.

This situation presents at least two general problems. First, passengers traveling from the United States may effectively, and relatively easily, circumvent the DOT Secretary's flight suspension order, making moot the U.S. Government's interest in safeguarding the public. Such circumvention is an indicator of the public's actual interest in reaching Lagos by air, even after given the warning of the potential dangers that exist at Lagos' airport. Therefore, such flight suspension could actually be seen to run contrary to the public's interest. Second, if a foreign air carrier can provide indirect service to the security-deficient airport and such air carrier is also one that could have provided the same service directly (i.e., a U.S. air carrier's competition), then the DOT Secretary's flight suspension decision effectively allows the foreign air carrier a competitive advantage over its American counterpart. The U.S. carrier would be prohibited from offering service directly, yet a foreign air carrier would be able to take passengers to the alleged security-deficient airport as long as it stopped first at a foreign destination other than the security-deficient airport. Even if a foreign air carrier did not directly compete with a U.S. air carrier for fares on the suspended route, the flight suspension still denies revenue to U.S. air carriers by forcing would-be passengers to foreign air carriers who can fly to the prohibited destination, albeit not from the U.S. The following discussion

12. ATA, for example, helped its passengers find alternate routes to Lagos, Nigeria in an effort to satisfy the passengers' expectation of passage. "Protection" is a term of art used in the air carrier industry to describe the practice where an air carrier that can no longer offer service to a certain destination (for whatever reason) will "protect" passengers with reservations to that destination by finding passage for those passengers on other air carriers. ATA employed this practice in an effort to help serve its customers who were affected by the flight suspensions to Lagos, Nigeria. 
explains how these general problems, or loopholes, manifest themselves as a result of current international and federal law.

\section{INTERNATIONAL AVIATION LAW With RESPECT TO the LAGOS AIRPORT FLIGHT SUSPENSIONS}

Before the U.S. legal processes allowing the DOT Secretary to suspend flights to Lagos, Nigeria are discussed, a brief analysis of international aviation law is necessary for understanding the facts surrounding the ATA situation outlined above. Also, a review of particular aspects of international aviation law provides a solid backdrop for understanding how international flights are regulated and allows an analysis of federal law regarding international flight suspension to be better understood.

\section{A. Bilateral Air Transport Agreements}

Civil air carrier authority to land in other countries is derived from contracts entered into by countries of such air carriers wishing to engage reciprocally in international air travel. These contracts are known as bilateral air transport agreements. The evolution and use of bilateral air transport agreements between countries as the primary way to govern and regulate civil international air services derives from a fundamental principle of air law described immediately below.

Countries engaged in international aviation claim an absolute sovereignty over the air space above their territories and territorial waters, including the right to impose regulations regarding the use of such space. ${ }^{13}$ When a foreign air carrier flies over U.S. territory, for example, it is subject to FAA regulations and all other federal laws. ${ }^{14}$ The reciprocal is also true: U.S. air carriers operating aircraft in and around foreign territories must abide by that country's aeronautical regulations. ${ }^{\text {is }}$

This right of sovereignty, always existent and enforceable, ${ }^{16}$ is selflimited when countries engaging in international commercial aviation form bilateral air transport agreements. ${ }^{17}$ Generally, these agreements contain

13. Convention on International Civil Aviation, supra note 6, art. 1.

14. Id. art. 11; See generally, Alaska Airlines, Inc. v. Sweat, 568 P.2d 916 (Alaska 1977) (holding that federal law preempts issues and subject matter involving aviation law).

15. Convention on International Civil Aviation, supra note 6, art. 1 .

16. Id. art. 5,6 , and 9 (b).

17. See Id. art. 6 (where no scheduled international air service into the jurisdiction of a contracting state may be operated without authorization by that country and in accordance with the terms of such permission. Historically, this authorization has taken the 
clauses granting specific rights for the two contracting parties to operate air services, on designated routes, at specified frequency, between the two countries. ${ }^{18}$ A bond of reciprocity becomes apparent to the extent that what is acceptable practice in one state constitutes acceptable practice in the other state, and vice versa.

\section{B. The Effect of Bilateral Air Transport Agreements}

As the name suggests, bilateral air transport agreements historically have not involved more than two sovereigns. These contracts, in their respective annexes, identify certain air routes linking the two contracting states. ${ }^{19}$ The agreements allow the contracting states to designate which air carrier(s), registered with their respective states, ${ }^{20}$ may pick up and let down passengers in their territories. These air routes may, but do not necessarily, involve intermediate points in a country not a party to that specific bilateral air transport agreement. ${ }^{21}$ Although an air route between two contracting states may involve a landing at an intermediary port not within the territory of either contracting state, bilateral air transport agreements do not, generally, allow passenger traffic originating from that nonparty country to board the flight. ${ }^{22}$ Such practice would remain the standard, even if the country of that intermediary point was a party to a separate bilateral air transport agreement with one or both of the contracting states. $^{23}$

To illuminate this practice, consider the following example: Country $\mathrm{A}$ and Country $\mathrm{B}$ are parties to a bilateral air transport agreement with each other (the "A-B Bilateral"). Country C is a party to a separate bilateral air transport agreement with Country A (the "A-C Bilateral"), and a party to another such agreement with Country B (the "B-C Bilateral"). The A-C bilateral does not include Country $\mathrm{B}$ as an intermediary point in any routes

form of bilateral air transport agreements.

18. See generally Agreement Between the Government of the United States of America and the Government of the United Kingdom of Great Britain and Northern Ireland Conceming Air Services, July, 23, 1977, U.S.-Gr. Brit., 28 U.S.T. 5368, 5373-5374 [hereinafter, Bermuda II].

19. See e.g. Id. art. 2, and Annex 1.

20. See The Convention on International Civil Aviation, supra note 6, at arts. 17,18 , (indicating that aircraft have the nationality of the state in which they are registered and no aircraft can be validly registered in more than one state); Bermuda II, supra note 18, art. 3; See supra note 6.

21. Bermuda II, supra note 18 , art. 2, and Annex 1.

22. Id. Annex $1, \S 5(1)$ and $\S 5(2)$.

23. Id. 
between Countries A and C. So, even though Countries A and B have a bilateral agreement, and Countries $A$ and $C$ have a bilateral agreement, an air carrier from Country A cannot travel to Country $C$ via Country B. The B-C Bilateral only applies to air carriers of those two countries, not of Country A, which is not a party to the B-C bilateral.

In light of the above scenario, consider this real example. The United States is a party to bilateral air transport agreements with both Great Britain and Nigeria. ${ }^{24}$ Each bilateral air transport agreement contains annexes that prescribe routes to be utilized by the party states. The U.S.-Nigeria Bilateral does not authorize a U.S. air carrier or Nigerian air carrier to travel to and from each other's territory by way of Great Britain. For this reason, it would be impossible for a U.S. air carrier, such as ATA, to circumvent the DOT Secretary's flight suspension by flying indirectly to Lagos via Great Britain (or any other non-party country). However, because Great Britain and Nigeria have their own bilateral agreement, flights between those two countries would still be permitted, assuming the British aeronautical authorities would not have found it necessary to suspend flights between Nigeria and Great Britain. ${ }^{25}$ Similarly, flights between Great Britain and the U.S. would still be available under that respective bilateral agreement, unless the United Kingdom's airports also were found security-deficient by the DOT Secretary, or the DOT Secretary otherwise found it necessary to suspend such flights.

However, no flight suspension order by the DOT Secretary has been issued with respect to flights between London, England's Heathrow International Airport, Gatwick International Airport, or any other international airport in the United Kingdom. But note that even if the DOT Secretary would suspend flights between the U.S. and the United Kingdom, passengers could still simply find air passage to Nigeria via any number of international air carriers serving other foreign cities. For example, ATA utilized the services of both a German air carrier and a Swiss air carrier, to help its affected passengers re-negotiate their itinerary to and from Lagos. ${ }^{26}$

24. See generally Bermuda II, supra note 18; Air Transport Agreement Between the Federal Military Government of the Federal Republic of Nigeria and the Government of the United States of America, April 27, 1978, U.S-Nig., 29 U.S.T. 3102 [hereinafter, The Nigerian Bilateral]. Nigeria.

25. To date, only the United States has suspended flights between it and Lagos,

26. See supra note 12. According to ATA, it aided its affected passengers by assisting them with finding passage on the German-flagged air carrier Lufthansa and the Swiss-flagged air carrier, Swissair. 


\section{THE AUthority Vested IN THE SECRETARy OF TRANSPORTATION}

Although the specific authority to suspend flights from the United States to a security-deficient airport is expressly granted in the Security Act, the DOT Secretary generally is guided by factors outlined in the Aviation Act. The Aviation Act provides the DOT Secretary with the authority to act in the public interest when regulating air commerce and provides specific factors that the DOT Secretary must consider when determining the public interest. First, the Aviation Act is discussed with respect to the public interest and the DOT Secretary's duties thereunder. Then, the Security Act is analyzed to highlight the specific authority vested in the DOT Secretary with respect to the Lagos flight suspension situation.

\section{A. The Federal Aviation Act of $1958^{27}$}

\section{The Department Of Transportation and the Federal Aviation Administration}

\section{a. Duties and Public Interest Factors}

As a provision of the Aviation Act, Congress called for the creation of the Federal Aviation Administration (FAA). ${ }^{28}$ One of Congress' principle purposes for creating the FAA included the implementation of an agency that would be responsible for promoting safe air travel and protecting lives and property both in the air and on the ground. ${ }^{29}$ In creating the FAA, Congress placed the agency within the Department of Transportation. $^{30}$ Furthermore, Congress mandated the FAA to "carry out .... [the] duties and powers of the [DOT] Secretary related to aviation safety. ${ }^{131}$ As an agency of the DOT, the FAA carried out the actual airport assessments that led to suspending flights to and from the Lagos airport, but these assessments were carried out only under the authority and auspices of the DOT Secretary. Because the FAA is an agency of the DOT, the DOT Secretary acts as the "mouthpiece" for all public notifications and otherwise takes the responsibility for the Lagos flight suspension.

27. Federal Aviation Act of 1958, Pub. L. No. 85-726; 72 Stat. 737.

28. Id. $\$ 301(\mathrm{a})$ (b), repealed by Public Law 97-449, \$7; 96 Stat. 2444, currently codified at 49 U.S.C. $\$ 106$.

29. H.R. Rep. 85-2360, at 1; See, National Organization for Reform of Marijuana Laws (NORML) v. Mullen, 608 F. Supp. 945 (D.C. Cal. 1985), remanded on other grounds 796 F. 2d 276 (9th Cir. 1986) (discussing the purposes for the creation of the FAA).

30. 49 U.S.C. $\S 106$ (a) (1994).

31. Id. $\$ 106(\mathrm{~g})(1)$. 
The Aviation Act, in general, directs the FAA (and thus the DOT Secretary), when carrying out its duties mandated by the Security Act (discussed infra), to consider "as being in the public interest [the regulation of] air commerce in a way that best promotes its development and safety." ${ }^{32}$ In this context, "air commerce" is not limited to economic concerns, but has been broadly construed so as to incorporate Congress' intent to promote air safety. ${ }^{33}$ Because the DOT Secretary must assume, by statute, that the public interest entails acting in a way that best promotes safety, it is arguable that the DOT Secretary had both the power and a duty to suspend flights to the Lagos airport. However, this theory assumes that the suspension best promoted safety. Furthermore, it assumes that, in terms of the public interest, this factor stands alone or should be considered before any other public interest factors, including economic public interest factors.

This conclusion seems to gain support from an examination of 49 U.S.C. $\S 40101$, where the public interest factors created by the Aviation Act, and which the DOT Secretary is mandated to consider when performing his or her duties under the Aviation Act, are outlined. ${ }^{34}$ Under this section, all the public interest factors the DOT Secretary is mandated to consider are juxtaposed with one another. ${ }^{35}$ Although Congress has recently re-codified this part of the Aviation Act, it did not substantively change these public interest factors, nor the Aviation Act in general. ${ }^{36}$ The re-codification makes it clear, however, which set of factors the DOT Secretary should consider in carrying out his or her duties given the situation or issue involved. ${ }^{37}$ If the situation included economic issues, the DOT Secretary is required to maintain a policy reflecting one set of public interest factors. ${ }^{38}$ If the situation involves safety issues, another, different, set of

32. 49 U.S.C. 40101(d)(1) (1994); See United States v. S.A Empresa de Viacao Aerea Rio Grandense (Varig Airlines), 467 U.S. 797, 821 (1984)( holding that the FAA "has a statutory duty to promote safety in air transportation, not to insure it.")

33. See Hill v. National Transp. Safety Bd., 886 F.2d 1275 (10th Cir. 1989).

34. 49 U.S.C. $\$ 40101(1994)$; the Aviation Act was re-codified by Congress on July 5, 1994 by Public Law 103-272, 108 Stat. 745.

35. Id.

36. Revision of Title 49, Transportation, United States Code, P.L. 103-272, 108 Stat. 745 at $\$ 1(a)$, where certain laws are "revised, codified, and enacted . . . without substantive change"; See, S. Rep. 103-265, 103rd Cong., 2nd Sess. 1994, 1994 WL 261999 (Leg. Hist.) at 1.

37. See H.R. Rep. 103-180 at 257; 1994 U.S.C.C.A.N. 1074 (indicating that the factors listed under 49 U.S.C. $\$ 40101$ (a) were only to be considered when the DOT Secretary acted on economic issues. Also, this legislative history indicates that the factors outlined under 49 U.S.C. $\$ 40101$ (c) and (d) were only to be considered by the DOT Secretary when determining issues of safety).

38. Id. 
factors is then used by the DOT Secretary to determine the interests of the public.

\section{b. The DOT Secretary Should Consider the Economic as Well as The Safety Interests of the Public}

The public interest factors the DOT Secretary is required to consider when carrying out his or her duties with respect to the economic aspects of air commerce include:

assigning and maintaining safety as the highest-priority in air commerce, ${ }^{39}$ preventing any deterioration in established safety procedures, recognizing the clear intent, encouragement, and dedication of the Congress to further the highest degree of safety in air transportation and air commerce, ${ }^{40}$ the availability of a variety of adequate, economic, efficient, and low-priced services without unreasonable discrimination, or unfair or deceptive practices, ${ }^{41}$ placing maximum reliance on competitive market forces and on actual and potential competition (A) to provide the needed air transportation system; and (B) to encourage efficient and well-managed carriers to earn adequate profits and attract capital, considering any material differences between interstate air transportation and foreign air transportation, ${ }^{42}$ encouraging entry into air transportation markets by new and existing air carriers and the continued strengthening of small air carriers to ensure a more effective and competitive airline industry ${ }^{43}$ [and] strengthening the competitive position of air carriers to at least ensure equality with foreign air carriers, including the attainment of the opportunity for air carriers to maintain and increase their profitability in foreign air transportation. ${ }^{44}$

An overview of some of these economic-based factors indicates that although safety in air commerce must be considered, other factors demand attention. The aforementioned factors, therefore, recognize the public's interest in considering safety as well as economic matters when regulating

39. 49 U.S.C. $\S 40101(a)(1)(1994)$.

40. Id. $\$ 40101$ (a)(3).

41. Id. § 40101(a)(4).

42. Id. \& 40101(a)(6).

43. Id. $\S 40101(\mathrm{a})(13)$.

44. Id. § 40101(a)(15). 
air commerce. Yet, Congress outlines an entirely separate set of factors the DOT Secretary must consider as being in the public interest when safety issues present themselves. ${ }^{45}$ These safety factors give no consideration to the public's interest in competitiveness, profitability, or affect on air transportation markets, all of which determine the quality and price of air service, among other things. By outlining the public interest factors in such a way that separates what the DOT Secretary should consider as being in the public interest, depending on whether the situation involves economic or safety issues, Congress failed to realize and account for the fact that safety and economy are issues present in nearly all air transportation decisions. The flight suspension to the Lagos airport, is no exception. It too involves issues of safety that call for action in the public interest which is inconsistent with the public's interest in low-cost, convenient international air travel. Because of this, the DOT Secretary cannot conclude that he or she truly acts in the public interest when only considering those factors outlined by Congress that solely apply to safety in air travel. Instead, any determination of the public interest must include equal consideration of the public's interest in economic issues related to air transportation.

Before the Airline Deregulation Act of 1978 [hereinafter called the Deregulation Act] amended the Aviation Act by terminating the Civil Aeronautics Board (CAB) (the FAA's predecessor), ${ }^{46}$ the delegation of duties and regulation-making authority were much broader and allowed the $\mathrm{CAB}$ wide discretion. Specifically, the Aviation Act's original public interest factors allowed the $\mathrm{CAB}$ a broad range of policies, many of them protectionist and anti-competitive in nature. ${ }^{47}$ Furthermore, the public interest factors used in determining economic situations were broad and over-reaching. ${ }^{48}$ The Deregulation Act modified these factors to accurately reflect the public's interest by allowing competition and other market forces to determine the regulation of aviation domestically and internationally. ${ }^{49}$ These modified factors outlined at 49 U.S.C. \$40101(a) specifically direct the DOT Secretary to stress competition, variety, and otherwise encourage the development of international transportation.

Therefore, the Deregulation Act first allowed market forces to determine the direction and amount of governmental intervention in the aviation industry and internalized the factors that the DOT Secretary supposedly considers when acting in the public interest, at least with respect to

45. See Id. § 40101(d).

46. S. REP. No. 329, 96th Cong., 1st Sess. 1979, 1980. The CAB has been replaced by the FAA.

47. H.R. REP. No. 95-1211, 95th Cong., 2nd Sess., (1978).

48. Id.

49. Id. 
economic situations. Because market forces predicate the need for unhindered competition in any industrialized nation, when the DOT Secretary is confronted with a situation that involves not only safety issues, but issues of economy, the DOT Secretary should have a duty to weigh economic public interest factors as well. Only by doing so can the DOT Secretary gauge clearly and accurately the true public interest with regard to situations like the security at the Lagos airport.

Even if the DOT Secretary could analyze the public interest factors in such a way, one could still argue that since the economic public interest factors also mandate the DOT Secretary to consider passenger safety when making decisions, ${ }^{50}$ those factors should subordinate the other factors listed in that subsection. ${ }^{51} \mathrm{~A}$ plain-language analysis of these factors, however, suggests otherwise. Consider the factor mandating the DOT Secretary to include safety as the highest priority in air commerce. ${ }^{32}$ Although Congress determined that safety should be the public's highest priority and interest, this does not mean that after the DOT Secretary considers all public interest factors, including the economic reality of the situation, the public interest in airport safety would mandate flight suspension to the Lagos airport. That is, the aggregate of the other factors which stress competition in a deregulated marketplace, could mandate that flights not be suspended, even in light of the fact that safety is the public's highest priority. This would be true especially if the demand to travel to a certain destination was great and there existed a reasonable public expectation of relatively inexpensive passage to such a destination.

This argument would be consistent with the flight suspension to the Lagos airport, since ATA alone had to deny passage via its airline to over 3,000 people. ${ }^{53}$ Many of these passengers incurred greater expense as they traveled to the Lagos airport indirectly and circumvented the DOT Secretary's flight suspension.

\section{Conclusion With Respect to the Federal Aviation Act's Purposes, Policy Statements and Public Interest Factors}

The Lagos airport flight suspension situation indicates that safety does

50. See supra text accompanying notes 37-38.

51. See supra text accompanying notes 39-44.

52. See id.

53. The author learned this through personal interviews with several ATA ticketing agents at ATA headquarters in Indianapolis, Ind. (Oct.-Nov. 1993), and through a telephone interview with general counsel for ATA at ATA Headquarters in Indianapolis, Ind.(Oct. 1994). 
not encompass the totality of what is deemed to be in the public interest. Passengers originally denied direct passage to Lagos by the DOT Secretary's order simply changed their itinerary and flew there indirectly along a route that the DOT Secretary had no authority to regulate. Such public action is clear evidence that the DOT Secretary should not be limited to a certain set of factors when determining the public interest in a situation involving safety and another set of factors to determine that interest if the situation is economic. This is true especially when the situation involves both kind of issues, such as the flight suspension to the Lagos airport. By suspending flights to the Lagos airport, the DOT Secretary caused U.S. carriers to incur substantial. losses, while those air carriers' foreign competition benefited. Also, the affected travelers incurred additional expenses in completing their indirect travel to that airport. Most importantly, the legal processes in place which allowed the DOT Secretary to effectuate these flight suspensions did not keep air passengers from the risks present at that airport because they were able to get around the flight suspension. Hence, the DOT Secretary must be guided by factors that consider the public interest more realistically, interests that are personified by the Lagos airport flight suspension situation.

These points indicate that the method used by the DOT Secretary in determining the public interest, for the purpose of carrying out his or her duties with respect to international airport security, need modification. This conclusion is bolstered by the fact that the DOT Secretary's suspension of flights did not achieve its public goal with respect to the Lagos, Nigeria flight suspensions, which was to keep the flying public away from the Lagos airport. An examination of The Foreign Airport Security Act sheds additional light on the suspect prudence of the Secretary's suspension decision. It lends further insight as to the modification of procedures for determining the public interest when the DOT Secretary exercises flight suspension authority with respect to security-deficient foreign airports.

\section{B. The Foreign Airport Security $A c t^{54}$}

The Security Act, signed into law on August 8, 1985, outlines the DOT Secretary's direct, technical authority for suspending U.S. and foreign air carrier flights operating directly between the United States and a foreign country's security-deficient airport. This Act gave the DOT Secretary the specific authority and procedures for suspending flights between the United

54. Foreign Airport Security Act, Pub. L. No. 99-83, §§ 551-559, 99 Stat. 190, 222 (1985). (signed into law as a section of the International Security and Development Cooperation act of 1985, Pub. L. No. 99-83) amending $\$ 1115$ of the Federal Aviation Act of 1958, 49 U.S.C. App. $\$ 1515$, repealed; re-codified at 49 U.S.C. $\$ 44907$ (1994)). 
States and Lagos, Nigeria. The Security Act expanded the DOT and FAA's role in foreign airport security as it attempted to respond to the growing number of terrorist attacks levied against the United States and its citizens. Impetus for formulation of such legislation occurred mainly as a result of the Trans World Airlines (TWA) flight 847 hijacking in Athens, Greece. 55 Before implementation of the Security Act, no legal mechanisms existed within the U. S. Government for identifying foreign international airports posing a substantial security risk to air passengers. Also, no effective procedures existed for conveying a message to users of such dangerous facilities. Finally, no procedures were available for correcting the security problems and preventing future ones. ${ }^{56}$

1. Requirements of the Security Act's Foreign Airport Assessment Program with Respect to the Lagos Flight Suspensions ${ }^{57}$

a. Assessments

The Security Act directs the DOT Secretary to assess, "At intervals the ... [DOT Secretary] . . . considers necessary, . . . the effectiveness of the security measures maintained at; (A) a foreign airport; (i) served by an air carrier; (ii) from which a foreign air carrier serves the United States; or (iii) that poses a high risk of introducing danger to international air travel; ..." 58 The Secretary delegates responsibility for security

55. Douglas B. Feaver, TWA Sees No Collusion By Athens Security Staff Guns, Grenades Brought Aboard Jet, WASH. PosT, June 18, 1985, at A10; See also International Security and Development Cooperation Act, $\S 558$ (citing Congress' express celebration of the hostage release, individual praise for the bravery of the Captain and flight crew, and condolences to the family of the Navy Petty officer who was killed during the altercation).

56. International Terrorism: 1985 Hearings and Markup on H.R. 2822 Before the Committee on Foreign Affairs and its Subcommittees on Arms Control, International Security and Science and on International Operations, House of Representatives, 99th Cong., 2d Sess. (1985).

57. Although the Aviation Act does not initiate any formal program by that name, it does prescribe several specific tasks for the FAA to carry out, and therefore, the General Accounting Office refers to these tasks and procedures as the "Foreign Airport Assessment Program." See General Accounting Office, RCED-89-45, Aviation Security: FAA's Assessments of Foreign Airports (1988); (hereinafter, GAO Report).

58. 49 U.S.C. $\$ 44907$ (a)(1) (1994). The author attempted to obtain the results of the assessment conducted at the Murtala Muhammed Airport (Lagos Airport), but has been denied access for security reasons. Furthermore, all mention of the flight suspension, whether through news release or otherwise, indicates that the Lagos airpon was closed to U.S, traffic because it failed to maintain proper security standards. No reports indicate how 
assessment to the FAA Office of Civil Aviation Security. ${ }^{59}$

Besides making these assessments, the Civil Aviation Security Office also must report to the Secretary of State any terrorist threat that exists at assessed airports in foreign countries and explain in detail whether that airport is operated under the "de facto" control of that country's government. ${ }^{60}$ The Office must also report its findings to the Secretary of Transportation especially when, based on the FAA's assessment, a foreign airport does not maintain or administer effective security measures. ${ }^{61}$ Finally, the Office must make an annual report to Congress giving a summary of the assessments conducted. ${ }^{62}$

\section{b. Notice}

The Security Act directs the DOT Secretary to notify the foreign government operating an airport assessed to be below international security standards that it is failing to maintain or administer effective security measures. ${ }^{63}$ Included in this notification must be recommendations to cure the security breaches. ${ }^{64}$ If the breaches are not remedied within ninety days of notification to that foreign government, the American public must be notified through all of the following: the Federal Register, mass media, a prominent public display of such notice in all U.S. airports offering regularly scheduled airline service to such an airport, and by the attachment of notices of the DOT Secretary's finding to the passenger tickets of all U.S. and foreign air carriers providing direct service between the U.S. and such airport. $^{65}$

the airport failed those standards. In an interview with the author, general counsel for ATA indicated that ATA had not been given the results of the FAA assessment, either.

59. GAO Report, supra note 57, at 2.

60. Id.; 49 U.S.C. $\$ 44907$ (b).

61. GAO Report, supra note 57, at 2 .

62. 49 U.S.C. $\$ 44907$ (a)(3). The FAA is required to submit such reports no later than December 31, 1991 of each year, pursuant to 49 U.S.C. $\$ 44938(b)$. At the time of this writing the FAA's latest report to Congress has not been made available. Even if such a report was available to the public, the DOT and FAA are permitted, pursuant to 49 U.S.C. 44938(b), to submit the report as classified. Therefore, it would be highly unlikely that any member of the public, could view the FAA's assessment or exact assessment procedures used at the Lagos airport. Further, if such information was made public, the FAA would, in effect, be publicizing to the world, including terrorists, the security-deficient aspects of a given airport.

63. Id. \$ 44907(c).

64. GAO Report, supra note 57 , at 2 .

65. 49 U.S.C. $\$ 44907$ (d). 
If, after consultation with the Secretary of State, the DOT Secretary determines that "a condition exists that threatens the safety or security of passengers, aircraft, or crew traveling to or from the airport," the Secretary need not wait ninety days before executing the notice procedures described above or the sanctions described below. ${ }^{66}$ However, the government of the country operating the security-deficient airport still must be consulted with regard to the assessment results.

\section{c. Sanctions}

The Security Act provides for sanctions in the event a foreign government does not remedy a security-deficient airport in its territory or the airport is not under the legitimate government's control. Such sanctions take the form of flight suspensions in two ways. First, the DOT Secretary is given the power to "withhold, revoke, or prescribe conditions on the operating authority of an air carrier or foreign air carrier that uses that airport to provide foreign air transportation." ${ }^{167}$ Conditions limiting this power are: (1) the DOT Secretary must consult with the appropriate aeronautical authorities of the foreign country; (2) the DOT Secretary must consult with each air carrier serving such airport; and 3) the decision must have been approved by the Secretary of State. ${ }^{68}$

The Security Act, does not specify exactly what is meant by the consultation or what issues are to be covered in such a consultation. ${ }^{69}$ Consultations are urged elsewhere by the Security Act, making it plausible that any such consultation with foreign governments should be of the same or similar nature. ${ }^{70}$ Similarly, DOT Secretary consultation with air carriers

66. Id. $\S 44907(\mathrm{~d})(2)(\mathrm{A})$.

67. Id. $\$ 44907(\mathrm{~d})(\mathrm{I})(\mathrm{C})$.

68. Id.

69. For example, the consultation simply could entail the Secretary informing the foreign government of the determination that its airport is substandard, and therefore, the U.S. is no longer allowing aircraft originating in the U.S. to fly to the airport. Or it may be a discussion including the procedures that need to be taken to bring the facility up to par, and how the government might best go about doing it. Similarly the consultation with each air carrier is unclear as to the contents and purpose of any such discussion.

70. Specifically, 49 U.S.C. $\$ 44907$ (c) requires that after an assessment of a foreign airport is made by the FAA and the DOT Secretary determines that such a facility is substandard with respect to effective security measures, the Secretary "shall notify the appropriate authorities of the government of the foreign country of the decision, and recommend the steps necessary to bring the security measures in use at the airport up to the standard used by the Secretary of Transportation in making the assessment. "Considering that the spirit of the Security Act is one of safe and prosperous air travel, as opposed to being an 
is urged in other parts of the Federal Aviation Act. ${ }^{11}$ Therefore, the Security Act appears to suggest that the required consultation encompasses more than a formal or simple notification, but rather some sort of briefing with respect to the situations, including any reasons for subsequent action.

Second, the DOT Secretary has the authority to suspend air service of any U.S. carrier or foreign air carrier between the U.S. and the substandard security foreign airport immediately, "with the approval of the Secretary of State and without notice or a hearing," provided that certain conditions are met. $^{72}$ These conditions include (1) an existing situation "that threatens the safety or security of passengers, aircraft, or crew traveling to or from ... [a foreign] . . . airport," and (2)" the public interest requires an immediate suspension of transportation between the United States and that airport." (emphasis added). ${ }^{73}$

\section{Analysis of the DOT Secretary's Authority to Suspend Fights to the Lagos Airport}

\section{a. After Assessment and Consultation}

There seems to be little difference between the two ways in which the DOT Secretary may suspend international flights to security-deficient airports. However, important differences exist. Under the Security Act, the DOT Secretary may suspend air carrier authority to operate into securitydeficient foreign airports after an FAA assessment has concluded that such an airport fails to adhere to airport security standards set out in Annex 17

being an Act for the purpose of reprimanding or economically hindering actors in international air travel, an assumption can be made that the consultation with the foreign government required by $\S 44907$ (d)(1)(C) should be one of the same nature as required by $\$ 44907$ (c). Note however, that if the Secretary acts within $\$ 44907(d)(1)(C)$, the Secretary should already have notified or otherwise consulted with the foreign government with regards to the FAA assessment, under $\$ 44907$ (c). This is evidence that the "consultation required by $\$ 44907$ (d)(1)(C), may indeed only encompass formal notification of U.S. intentions with regard to flights from the U.S. to that airport, and not necessarily a problem-solving consultation.

71. See e.g. 49 U.S.C. $\$ 40105(c)$ (1994) (where consultation with air carriers is required, ". . . to the maximum extent practicable ..." in developing and implementing international aviation policy).

72. 49 U.S.C. $\$ 44907(\mathrm{e})$.

73. Id. 
of the Chicago Convention. ${ }^{74}$ Generally, these flight suspensions are allowed only after consultation with the government controlling the substandard airport, and only after DOT Secretary recommendations are made (through the FAA) regarding ways the deficiencies can be remedied. ${ }^{75}$ Also, the DOT Secretary must wait ninety days to allow the foreign government time to bring the deficient airport up to international standards before " withhold[ing], revok[ing], or prescrib[ing] conditions on the operating authority of an air carrier or foreign air carrier that uses that airport to provide foreign air transportation. ${ }^{176}$ The only exception to the ninety day rule presents itself if a condition exists where the safety or security of passengers, aircraft, or crew traveling to or from such an airport is certainly compromised. ${ }^{77}$ If such an imminently dangerous condition exists, the DOT Secretary may immediately withhold, revoke, or otherwise impose conditions on the U.S. and foreign air carriers that operate flights directly between the United States and the foreign airport. ${ }^{78}$ However, even if a condition exists that relieves the DOT Secretary's duty to wait ninety days, consultation with the foreign government, nonetheless, is still mandatory and an assessment must be completed. ${ }^{79}$

\section{b. Without Assessment and Consultation}

The DOT Secretary, in certain circumstances, has much broader flight suspension authority. Under the Security Act, the Secretary may suspend the right of a U.S. or foreign air carrier to engage in foreign air transportation between the U.S. and that foreign airport, regardless of whether the FAA assessed the foreign facility, when certain conditions exist. ${ }^{80}$ Also, no consultation with the foreign government is required, nor does the DOT Secretary need to provide any recommendations to the foreign government, when these conditions exist. ${ }^{81}$ The DOT Secretary's authority to execute

74. 49 U.S.C. $\$ 44907$ (a)(2)(C) requires that the FAA use "a standard that will result in an analysis of the security measures at the airport based at least on the standards and appropriate recommended practices contained in Annex 17 to the Convention on International Civil Aviation ...." Annex 17 outlines minimum international airport security standards. These standards must be adhered to by all countries who are a party to the Agreement. Nigeria is a party to this agreement.

75. Id. $\S 44907$ (a)(2)(A),(c).

76. Id. $\S 44907$ (d)(2)(A)(i), (d)(1)(C).

77. Id. $\$ 44907$ (d)(2)(A)(ii).

78. Id.

79. Id. \& 44907 (c).

80. Id. $\$ 44907$ (e); See supra text accompanying notes 72-73.

81. Id. 
such suspensions, however, is still subject to the consultation with and approval of the Secretary of State. ${ }^{82}$ No waiting period is required, either ninety days or otherwise, as the Secretary's suspension authority is immediate when there is an existing life threatening condition, or the public interest requires such action. ${ }^{83}$

\section{c. Authority Beyond That of the DOT Secretary Under The Security Act}

The Security Act allows the U.S. President even broader flight suspension authority than the DOT Secretary regarding air travel between the United States and security-deficient foreign airports. Specifically, the Security Act allows the President to prohibit air carriers and foreign air carriers from providing service between the United States and any other foreign airport that is directly or indirectly served by aircraft flying to or from the foreign security-deficient airport. ${ }^{84}$ Note that this Presidential authority acknowledges and closes the 'loophole' that passengers use to circumvent the DOT Secretary's suspension order with regard to flights between the United States and Lagos, Nigeria. Under this authority, for example, flights to other foreign airports that serve air carriers which in turn serve the Lagos airport would be off limits to any international air carriers leaving the United States. Thus, ATA's passengers who were affected by the DOT Secretary's flight suspension could not have traveled to the Lagos airport via another international airport, e.g. London's Heathrow, if the President ordered the flight suspension. Because of the strong political effect such action would cause, however, ${ }^{85}$ the President's flight suspension authority has not been exercised under the Security Act.

\section{The Security Act and the Lagos Flight Suspensions}

Considering the facts surrounding the DOT Secretary's flight suspensions to Lagos, it is clear that the DOT Secretary acted under the lesser authority of the Security Act. $^{86}$ That is, the FAA conducted a formal assessment in September $1992 .^{87}$ At that time the FAA found that the

82. Id.

83. Id.

84. 49 U.S.C. $\$ 44907$ (d)(1)(D).

85. For example, such a flight suspension might violate clauses of the various Bilateral Air Transport Agreements; See supra text accompanying notes 13-26.

86. Aviation Proceedings Notice 92-20, 57 Fed. Reg. 47367-01 (1992); 49 U.S.C. $\$ 44907$ (a)-(d).

87. U.S. Department of Transportation News Release, supra note 3, at 1. 
security measures used at the Lagos airport did not meet the standards established by Annex 17 of the Chicago Convention. ${ }^{88}$ After this assessment, the DOT Secretary accordingly confirmed that the Lagos airport did "not maintain and administer effective security measures." ${ }^{\text {"9 }}$ The DOT Secretary also found that conditions existed which presented a danger to passengers, aircraft, and crews at the Lagos airport. ${ }^{90}$ This meant that the DOT Secretary did not have to wait ninety days before exercising his flight suspension authority. ${ }^{91}$ However, in this situation, the DOT Secretary chose not to exercise the suspension authority immediately, but required U.S. and foreign air carriers to subscribe to the publication requirements notifying all passengers of the deficient security at the Lagos airport. ${ }^{92}$

In accordance with prescribed procedures, the DOT Secretary published a notice regarding the FAA's security assessment of the Lagos airport in the Federal Register, presumably displayed these findings prominently in all U.S. airports regularly being served by scheduled air carrier operations, ${ }^{93}$ and alerted the news media. ${ }^{94}$ In addition, the Secretary ordered that all U.S. and foreign air carriers serving the Lagos airport directly via the United States serve written notice to any passengers buying tickets to the Lagos airport of the Secretary's findings and determinations regarding the substandard safety environment of the Lagos airport. ${ }^{95}$

Finally, the DOT Secretary presumably notified the Nigerian government regarding the FAA's assessment results, and, since October 8, 1992, "the Federal Aviation Administration has provided substantial technical assistance to the Nigerian government to help it improve the airport's security."

\section{EFFECT OF DOT AUTHORITY ON THE ATA-Lagos Situation}

By analyzing the authority given to the DOT Secretary with respect to international aviation and discussing how it applied to the ATA-Lagos

88. Id.

89. Aviation Proceedings Notice 92-20, supra note 86, at 1.

90. Id.

91. See supra text accompanying notes 74-79.

92. Aviation Proceedings Notice 92-20, supra note 86 , at 1 .

93. A warning is prominently displayed in several places at the Indianapolis International Airport, Indianapolis, Ind.

94. U.S. Suspends Flights to Nigeria, S.F. CHRON., Aug. 12, 1993, at A11; 49 U.S.C. $\$ 44907$ (d). In executing these procedures the DOT Secretary acted pursuant to $\$ 1115$ (e)(2)(A) of the Security Act, now repealed and recodified.

95. Aviation Proceedings Notice 92-20, supra note 86, at 1 ; 49 U.S.C. $\$ 44907(d)(1)(B)$.

96. 49 U.S.C. $\$ 44907$ (c); U.S. Department of Transportation News Release, supra note 3 , at 1 . 
situation, several issues present themselves in light of the two general problems caused by the current federal law (outlined earlier). These include (1) the appropriateness of the DOT Secretary's authority under the Security Act, especially considering the DOT Secretary's duty to act in the public interest; (2) the misuse of the Security Act as a political tool instead of a public safety tool; and (3) the Security Act's simple inability to successfully prohibit travel to allegedly unsafe airports.

\section{A. The Security Act and the Public Interest}

The DOT did not detail to the public how the Lagos airport failed to adhere to Annex 17 of the Chicago Convention. ${ }^{97}$ However, this refusal to give detail was most likely motivated by the very real possibility that exposing such information could cause a major crisis in the form of a terrorist attack or similar tragedy. ${ }^{98}$ At any rate, without such information, it remains difficult to analyze whether the DOT Secretary had grounds for exercising the authority to discontinue the operations of U.S. and foreign air carriers between the United States and Lagos.

What should be clear from the ATA-Lagos airport situation, however, is the fact that the Security Act vests in the DOT and State Secretaries the power to suspend U.S. air carrier and foreign air carrier flights between the United States and a given airport even though the act of suspension may not necessarily, or likely, keep travelers safe. At the same time, the flight suspension effectively gives American air carrier business away to foreign competitors. Under certain circumstances, actions may be taken without regard to whether the FAA assessed the foreign airport for security deficiencies. ${ }^{99}$ Also, these actions with respect to a foreign airport that have not been assessed by the FAA may be taken immediately, especially if the DOT Secretary determines, in his discretion, that public interest mandates immediate action. ${ }^{100}$

The DOT Secretary is required to consider the factors that the Federal Aviation Act mandates to be taken into account when determining the public interest. $^{101}$ Where no security assessment has taken place, ${ }^{102}$ however,

97. U.S. Suspends Flights to Nigeria, supra note 94.

98. See e.g. GAO Report, supra note 57 at 1; The GAO did not even relinquish the names of the airports where the FAA had done assessments, nor the specific results of such reports, to the Honorable Cardiss Collins, Chairwoman of the Subcommittee on Government Activities and Transportation, Committee on Government Operations, House of Representatives.

99. See 49 U.S.C. $\$ 44907(\mathrm{e})$.

100. Id.

101. See supra text accompanying notes 27-53. 
the DOT Secretary cannot (1) determine if a condition exists which truly threatens the safety of passengers, aircraft and crew with respect to airport security, and (2) should not act where safety is declared to be the most important factor.

Without an FAA assessment of a foreign airport, there is no other accurate way to gauge the safety of a foreign airport, or the amount and likelihood of risk to passengers, aircraft, and crew. The need for an assessment is especially acute when a foreign airport faces a situation (such as a terrorist factor) that could test its security processes. Without this assessment the DOT Secretary may be left to make suspension decisions using information not specifically dealing with the airport's security measures.

\section{B. Abuse of the Foreign Airport Security Act}

Cases in which a foreign country may be experiencing political strife present particular problems. For example, assume that regularly scheduled air carriers from the United States and the foreign country both offer air service between the United States and an airport in that country. Assume further that the FAA has not conducted a recent assessment to determine whether the airport meets international safety standards. Political strife might be a factor to consider in determining the safety of the international travelers at that airport. In fact, the Security Act mandates that when assessing foreign airports, in addition to on-site observations of the facility, the DOT Secretary must consult with the Secretary of State to determine whether such an airport is under the "de facto control" of the country in which it is located. ${ }^{103}$

When the DOT Secretary acts pursuant to that part of the Security Act codified at 49 U.S.C. $\$ 44907$ (e), the DOT Secretary must still acquire the approval of the Secretary of State, even though no airport security assessment need be executed. The Security Act, however, does not specify what the consultation must contain or in what detail it must be composed. In contrast, when the DOT Secretary suspends flights to a given country's security-deficient airport under the part of the Security Act codified at 49

102. Although the FAA in fact conducted a security assessment of the Murtala Muhammed International Airport in Lagos, Nigeria, discussion of the DOT Secretary's wide discretion and broad authority under the part of the Security Act codified at 49 U.S.C. $\$ 44907$ (e) further illuminates the Aviation Act's shortcomings with respect to its purpose of safeguarding international travel. Because this Comment details the Security Act, a discussion of this section of the Security Act is warranted.

103. 49 U.S.C. $\$ 44907(b)$. 
U.S.C. $\S 44907$ (d)(1)(c), and after an FAA assessment, the DOT Secretary consults the U.S. Secretary of State to determine whether that country's recognized government had control over the airport. There is little question under this part of the Security Act that the required consultation should be undertaken in the spirit of foreign airport security, and should center around the FAA security assessment.

The part of the Security Act codified at 49 U.S.C. $\$ 44907$ (e), however, does not specify what the consultation with the Secretary of State should concern, even though it allows the DOT Secretary to immediately suspend flights to a foreign airport as soon as the Secretary of State grants approval. In effect, this means that the "consultation" could consist of non-airport security matters. Even if the consultation involves the welfare of U.S. citizens, the DOT Secretary is acting ultra vires of the Security Act, if a consultation on a given airport does not focus on its security.

If the DOT Secretary consults with the Secretary of State and then chooses to suspend flights, the decisive act is still beyond the scope of the Security Act if the airport in question had consistently maintained its security at or above international security standards and political strife motivated the decision. Therefore, this part of the Security Act gives the DOT Secretary something akin to an emergency power, along with wide discretion to apply it. This discretion includes the power to suspend direct flights even without an assessment of the airport in question. The DOT Secretary, upon consultation with, and affirmation from, the Secretary of State, can suspend flights indefinitely. As long as the DOT Secretary believes that a condition exists which threatens the safety of passengers, as well as aircraft and crew, and that the condition creates a situation in which the public interest demands flight suspension, this severe administrative action would be deemed appropriate under the Security Act.

Notice that such discretion can be used politically, instead of truly safeguarding the well-being of passengers and airport personnel alike. For instance, if political strife ignited in a country, and the conflict ran counter to the interests of the U.S. government, the DOT Secretary could capriciously suspend flights into any or all the airports of that country in surreptitious response to the political nature of the strife, regardless of whether there was any evidence concerning a potential security breach resulting from the strife.

\section{Politics Involved With the ATA-Lagos Situation?}

In a country such as Nigeria, which has very few airports that can accommodate international air traffic, cutting off flights to and from the United States could deal that country a devastating economic blow. It is conceivable that the resultant economic hardship could, if only indirectly, 
cost the proponents of a popular political movement success. Obviously, in this light the Security Act can be a powerful political tool, limiting international access to such a country. Note also that by having the DOT Secretary suspend flights under a safety ruse, the U.S. Government, and particularly the U.S. President, does not have to engage in an international debate about economic sanctions or otherwise incur criticism for sanctioning a country because of disapproval of its government or dissident activities.

\section{Politics in Nigeria}

Though she is Africa's leading actor on the global stage, Nigeria presently finds herself teetering on the edge of a national political breakdown. In June of 1993, the Nigerian military annulled the result of the presidential elections, the first elections held in ten years. ${ }^{104}$ Nigeria's new controlling military regime has been condemned both outside and within Africa for detaining human rights activists and banning newspapers that criticize the government. ${ }^{105}$ As Africa's most populous and industrial nation, Nigeria looked forward to being chosen as the African continent's leading choice to fill a permanent seat on the United Nations Security Council. ${ }^{106}$ However, "for Nigeria to have more claim to the seat than South Africa, there is the need to show more positiveness about the new world order, which is predicated on democracy."107 The recent hindering of elections and banishment of the country's free press flies directly in the face of the democracy-based new world order. Consequently, this has caused major players in the new world order and Nigeria's traditional allies, the United States and Great Britain, to invoke sanctions against the un-elected Nigerian military government. ${ }^{108}$

Some observers and reporters believe that the flight suspension by the DOT Secretary was entirely political and had nothing to do with the actual security standards at the Lagos airport. The Detroit Free Press reported that the U.S. "invoked sanctions against [the Nigerian military] government . . . [which] included discontinuance of military training and supplies to Nigeria ... [and the suspension of] commercial flights to and from Nigeria and reduced the number of visas being issued to Nigerians." 109 The day the

104. Remer Tyson, Nigerians see Nation in Retreat: Once Powerful Country Suffers Great Anxiety, DET. Free Press, Aug. 21, 1993 at 4A.

105. Id.

106. Id.

107. Id. (quoting Dr. Bola Akinterinwa, a senior research fellow at the Nigerian Institute of International Affairs, Lagos, Nigeria).

108. Id.

109. Id. 
DOT released news of the suspensions, the San Francisco Chronicle reported that "the action has been under consideration since September because of unspecified security problems ... [and that] . . Nigeria is on the eve of a nationwide protest against the military dictatorship's refusal to relinquish power." 110

It can be argued that the political uprising Nigeria experienced in 1993 caused an unsafe condition at the airport because the airport could not demonstrate (to the satisfaction of the DOT Secretary) adequate safeguards protecting the flying public from terrorist attack. However, it is possible that the executive branch of the U.S. Government, in response to the political changes in Nigeria, employed the Security Act to impose a political sanction by cutting its traffic to and from the United States under the guise of deficient airport security. If so, the DOT Secretary and the U.S. Government abused its authority under the Security Act.

\section{PREsidential Authority Under The Security ACt}

The DOT Secretary is not the only federal office given the power to affect foreign air commerce under the Security Act. As mentioned earlier the President has considerable authority to suspend flights to securitydeficient foreign airports, including such operations as ATA's flights to Lagos. In fact, this Presidential authority is much broader and less discriminatory than the suspension powers of the DOT Secretary.

\section{A. Presidential Flight Suspension Authority}

Under the Security Act, the U.S. President has the power to close the loophole that allows indirect travel to security-deficient airports even though direct flights between foreign security-deficient facilities and the United States have been suspended. Under the Security Act, "the President may prohibit an air carrier or foreign air carrier from providing transportation between the United States and any other foreign airport which is directly or indirectly served by aircraft flying to or from the airport with respect to which the determination is made under this section."111 According to the Security Act, however, this subsection only applies to airports that have already been assessed by the FAA. ${ }^{12}$ Like the DOT Secretary's authority, Presidential prohibition can be enforced immediately if a condition exists

110. U.S. Suspends Flights to Nigeria, supra note 94.

111. 49 U.S.C. $\$ 44907$ (d)(1)(D).

112. Id. § 44907(c). 
that threatens the safety of passengers, aircraft, or crew, but only if the FAA conducted an assessment first. ${ }^{113}$

\section{B. Flight Suspensions for Political Purposes and The Security Act}

Note that the Security Act grants the President the authority not only to suspend those flights that operate directly between the United States and a foreign security-deficient airport, but also flights serving other foreign airports known to accommodate air carriers that carry passengers to the security-deficient airport. However, this authority is only granted upon the condition that an FAA assessment is first carried out and a determination made that a security deficiency actually exists at that foreign airport.

The President has no authority to suspend flights that directly or indirectly serve a foreign airport when no assessment was done-even if the President finds that (1) a condition exists which affects the safety of passengers, aircraft, and crew and (2) the public interest might well be served by such a sweeping suspension. Therefore, the Foreign Airport Security Act was not meant to be used as a political tool, but instead, to be used with discretion, and only as it regards deficient foreign airport security practices indicated by FAA investigation and assessment. Furthermore, the fact that the President possesses such broad power provides a reasonable basis for concluding that the loophole allowing travelers to by-pass the flight suspension was known to Congress because Congress gave the President a specific way to close it.

\section{The Effect of Exercising Presidential Authority Under The Security Act}

The most obvious reason why the President retains sole authority to prohibit flights that indirectly service a security-deficient airport, while the DOT Secretary does not, concerns the effect of such power. This power is reserved for the President because of the enormous economic and political effect such a decision would have. By prohibiting even indirect flights from the United States to a security-deficient foreign airport, the President would be taking action akin to an international boycott. ${ }^{114}$

Recall the facts involved with the suspension of flights into the airport

113. Id. $\S 44907(\mathrm{~d})(1)(\mathrm{D})$.

114. See H.R. CONF. REP. No. 237, 99th Cong., 1st Sess.(1985), 1985 U.S.C.C.A.N. 210, 1985 WL 47111, (describing the House Amendments to the Security Act before its passage. Here, such action by the President was described as a "general air carrier boycott with respect to such airports"). 
at Lagos. In that situation, passengers could still travel to Lagos via any number of foreign airlines and other foreign airports. In fact, ATA helped the passengers who were originally scheduled to fly to Lagos by booking alternate transportation routes via other foreign air carriers. ${ }^{15}$ ATA flew many of these passengers to a gateway city, like New York City's John F. Kennedy International Airport, where the passengers then boarded foreign air carriers such as Swissair, Lufthansa, and British Airways bound for London's Heathrow Airport. ${ }^{116}$ From London, passengers found passage to the Lagos airport on either the same or a different foreign carrier. However, if the U.S. President executed his authority under the Security Act, as described above, ${ }^{117}$ he could have suspended all U.S. and foreign flights offering service between any point in the United States and London's Heathrow airport.

Such Presidential action, however, would probably have had catastrophic economic and political consequences. ${ }^{118}$ First, the costs far outweigh the benefits that would be derived. In this era of interglobalism and international economics, cutting the lifelines between points in the United States and countries like Great Britain would paralyze international business and trade. Second, because authority for foreign air carrier operation in a given country is based on bilateral air transport agreements between the two countries and their airlines, and because these bilateral agreements generally operate on a basis of reciprocity, backlash from the affected countries would be imminent.

\section{CONCLUSIONS AND RECOMMENDATIONS}

Highlighting the suspension of flights into Lagos' Murtala Muhammed Airport and analyzing the legal apparati providing the authority to effectuate that flight suspension exposes inadequacies regarding the United States Government's practice of international flight suspension. Specifically, through analysis of certain aspects of the Security Act, international flight suspension by the DOT Secretary (1) fails to keep the flying public away from security-deficient international airports; (2) hinders U.S. carrier competitiveness in international markets, especially small U.S. carriers such

115. The author learned this through personal interviews with several ATA ticketing agents at ATA headquarters in Indianapolis, Ind. (Oct.-Nov. 1993), and through a telephone interview with counsel for ATA at ATA Headquarters in Indianapolis, Ind.(Oct. 1994); See supra note 26.

116. Id.

117. See also supra text accompanying notes 84-85.

118. This Presidential power has never been invoked. 
as ATA; and (3) grants a vague authority to the DOT Secretary that enables he or she to act without accurately gauging the public interest.

\section{A. Two Approaches}

Because the Security Act cannot safeguard a member of the flying public that intends to travel to a security-deficient airport unless the Presidential authority under the Security Act is invoked, and because the President's authority may never be invoked because of the political and economic backlash that would likely result, approaches should be taken either to (1) amend the Security Act and/or (2) continue the pursuit of total harmonization of international aviation standards, while focusing on international airport security standards as an integral component of such harmonization. Furthermore, the need for implementation of one or both of these approaches appears not only from the fact that the U.S. Government cannot effectively keep the flying public from traveling to security-deficient airports, but also due to the fact that acts of direct suspension are economically crippling to U.S. air carriers engaged in international air commerce.

\section{Amending The Security Act or Otherwise Curbing U.S. Government Authority to Suspend International Flights}

\section{a. Let the Market Rule}

It is possible to argue that as long as the Security Act effectively keeps one passenger from flying to a security-deficient foreign airport, thereby safeguarding that passenger's exposure to the associated dangers, the Security Act fulfills its purpose. This argument, however, fails to consider the costs resulting from taking such action. Costs include loss of revenues, hindrance of competitiveness, and the loss of personal benefits enjoyed by travelers when they may travel freely.

The Security Act should be fundamentally amended to alleviate this problem. The Security Act should not grant the DOT Secretary or the President authority to suspend flights due to foreign security-deficient airports. The DOT Secretary should, however, continue notifying the traveling public of the status of security-deficient airports and the concomitant risks. Ultimate decisions regarding flying to a security-deficient airport should be made by passengers, air carriers, and the air carrier's insurer. Government should assume only an advisory and persuasive role regarding flight suspension decisions due to a security-deficient foreign airport, unless there is a bona fide threat to national security. Although Congress may have had good intentions when it enacted the Security Act to combat 
terrorist attacks against U.S. air carriers and citizens, the flight suspension to Lagos has demonstrated how these good intentions have actually caused adverse results. Because of the state of international aviation law, government intervention in the form of flight suspensions burdens U.S. domestic carriers more than it does their international competitors. The Security Act cannot prohibit U.S. passengers from utilizing foreign air carriers to reach a prohibited destination absent a Presidential decree, ${ }^{119}$ so such loss in revenues is directly incurred by U.S. carriers.

Instead, the capitalist consumer market can better determine whether flights to security-deficient airports should be suspended. After receiving appropriately detailed information by the DOT Secretary in the manner outlined by the Security Act, a traveler can make an informed decision. Similarly, air carriers would be free to make a private suspension decision, weighing factors such as cost of insurance coverage, whether such insurance would cover such flights, and the opportunity cost of losing those passengers to other air carriers. The U.S. Government can best fulfill its role as protector by providing necessary information regarding the security status of foreign airports, while using diplomatic pressure to advance security interests.

\section{b. Suspending International Flights in a Less-Discriminatory Way}

Note that by deleting certain parts of the Security Act, U.S. Government flight suspension authority over security-deficient foreign airports would be eliminated. Other federal laws would continue to allow the U.S. government broader power in suspending international flights, generally. Flight suspension power would be broader where it allows flight suspension of more, if not all, foreign air carrier flights where the Security Act does not. By suspending all flights, the prejudice against domestic air carriers inherent in the Security Act would be precluded.

For example, The Aviation Act provides for the authority to suspend international flights for political reasons, including terrorist concerns. Section 1114 of the Aviation Act allows the President broad discretion in suspending the right of "an air carrier or foreign air carrier to provide foreign air transportation to and from that foreign country" that in any way arms, aids, or abets any terrorist organization within its jurisdiction. ${ }^{120}$

119. As discussed supra such Presidential action would be unrealistic, unless there existed some kind of national security emergency, because of the international economic and political ramifications the United States would surely suffer. See supra text accompanying notes 111-118.

120. 49 U.S.C. $\$ 40106(b)$ (1994). 
This suspension authority also applies to foreign air carriers that serve the targeted country and the United States, but which may not serve the United States and the targeted country directly. ${ }^{121}$ That is, this section prohibits foreign air carriers who serve the United States from flying to a nation that maintains any kind of air link between itself and the terrorist-infested nation. ${ }^{122}$

Note that such authority closes the loophole that the Security Act allows: It prohibits a traveler from flying from the United States to an off-limits nation indirectly via a third nation. Recalling the ATA example, passengers would not be able to travel first to London and then negotiate passage via any number of airlines to the Lagos airport. Under the Presidential authority of $\S 1114$, that traveler could not make it to Heathrow because all flights to that airport from the United States would be suspended on the basis that Great Britain would be a nation providing air passage to Nigeria.

Section 1114 of the Aviation Act has been used on several occasions to suspend flights between the United States and countries that are on the brink of war or suffering various kinds of political strife. For instance, President Bush exercised $\$ 1114$ of the Aviation Act to block the execution of sales and other transactions between the United States and the Federal Republic of Yugoslavia in 1992. ${ }^{123}$ The embargo included "any transaction by a U.S. person, or involving the use of U.S.-registered vessels and aircraft, relating to transportation to or from [Yugoslavia], the provision of transportation to or from the United States by any person in [Yugoslavia] ... or aircraft registered in [Yugoslavia]." 124 Another example of the use of $\$ 1114$ of the Aviation Act includes the prohibition of trade and certain transactions (including air carrier transactions) with Libya executed by President Reagan in 1986. ${ }^{125}$

\section{Harmonization of Law Regarding Foreign Airport Security}

Another approach, more complex and harder to implement, would be the harmonization of law regarding international airport security standards. International airport security standards are already harmonized to a great extent. ${ }^{126}$ However, the procedures to be followed and the sanctions incurred when an international airport fails to meet those standards are not.

121. Id. $\$ 40106(1)(C)$.

122. Id.

123. Exec. Order No. 12,810, 57 Fed. Reg. 24, 347 (1992).

124. Id.

125. Exec. Order No. 12,543, 51 Fed. Reg. 875 (1986).

126. See The Chicago Convention, supra note 6, Annex 17, Chapters 2 and 3. Contracting states to the Chicago Convention, for example, all agree that their respective airports should at least meet the international standards set out in Annex 17. 
The Chicago Convention, to date signed by 162 contracting states, provides a solid international basis for the harmonization of international aviation safety standards. ${ }^{127}$ Relatively large steps have already been taken within the last decade by countries engaging in international air transportation to harmonize aviation regulations. ${ }^{128}$ However, little harmonization has been accomplished with respect to either enforcement of airport security standards or to uniformity of sanctions for lax standards. ${ }^{129}$

If harmonization with regard to international airport security would be established, situations like the ineffective flight suspensions to Lagos would be eliminated. Upon the FAA/DOT finding that the Lagos airport fell below international security standards, all countries serving the Lagos Airport automatically would come to the same conclusion due to harmonized regulations and practices. Furthermore, all countries would take the same action: suspend direct flights to that security-deficient airport. Note, however, that such aviation law harmonization on an international scale, would, in a sense, contradict this Comment's aforementioned solution to the U.S.-enforced international flight suspension problem. This solution included keeping government out of the actual enforcement of suspension decisions, altogether, unless there existed a bona-fide national security emergency, at which time U.S.-enforced international flight suspension would apply to all air carriers, foreign as well as domestic.

But, this harmonization solution need not necessarily conflict with the notions of government non-interference and free-market rule. Alternatively, the international community could harmonize international aviation law in a way that prohibits government interference, except in an advisory capacity, and otherwise lets free-market forces determine which air carriers, if any, will fly to airports found by governments to be security-deficient. An international community whose aviation laws were harmonized in such a way would advise the flying public of the potentially dangerous situation at a given airport, but ultimately let individual carriers decide whether to continue offering flights to such destinations. Here, the foreign and

127. Memorandum on ICAO: The Story of The International Civil Aviation Organization, ICAO Doc. 312031 A, 1990 (on file with the author).

128. For example, the European Community formed the Joint Aviation Authorities (JAA) as a counterpart to the U.S.'s FAA. Since the inception of the JAA, numerous projects have been undertaken to harmonize the regulations of the U.S. with those of Europe, such as airworthiness standards for aircraft and design certification. Such harmonization insures that equipment that passes inspection in one country will pass inspection in the other country since the regulations are of the same caliber, and therefore, no re-inspection or certification is necessary before the equipment can be used in the latter country.

129. For a very detailed analysis of the FAA/JAA harmonization process, See generally Professor George A. Bermann, Regulatory Cooperation with Counterpart Agencies Abroad: The FAA's Aircraft Certification Experience, 24 LAW \& POL'Y INT'L BUS. 669 (1993). 
domestic air carriers (and their insurers) would decide whether to assume the risk of offering such service. Presumably, the market demand for such service would be the controlling factor. By allowing such freedom, the international air passenger would have better travel choices and services available rather than the hassle he or she is faced with presently as a result of the current federal law.

Theodore Edward Rokita*

* J.D. Candidate, 1995, Indiana University School of Law-Indianapolis; B.A., Wabash College. 